\title{
Recovery Plan as a Living Document, the Albanian Sight
}

\author{
Ermal Haxhiaj ${ }^{1}$, Artur Ribaj ${ }^{2}$
}

\begin{abstract}
The Recovery Plan is a document that introduces the possible measures of recovery that banks may take to restore the bank's viability and provide business continuation as a response to the scenario that may pose threat to this continuation. The Recovery Plans (RPs) must include a comprehensive menu of recovery options that can be undertaken in case of idiosyncratic or systemic adverse scenarios. In this context, banks are also required to analyze the implementation risks and probability of success of these measures, as well as identify ways to mitigate these risks. The bank shall consider these measures as solutions of extraordinary nature, which shall not be taken during the normal conduct of business. Recovery Plans aim to reduce the probability of failure of systemically important banks in Albania. Banks in Albania, in preparing the Plans, have to consider the basic supposition that in this process no support of public funds (funds of tax payers) shall be provided to restore their financial health. The bank recovery plan either by the bank or by the supervisory authority should be viewed as a living, breathing document that can and should be updated frequently, as needed.In this way it willbe kept realistic and practical aiming the minimization to zero of the public fundinginterventions.
\end{abstract}

Keywords: recovery plan, qualitative and quantitative indicators,

\section{Introduction}

A bank should establish a sound business continuity management to ensure its ability to operate on an on-going basis and limit losses in the event of severe business disruption. Starting from May 2012, the Bank of Albania required systemically important banks to prepare and submit RPs. This decision was taken being proactive in management of crises time and after consultations with international financial institutions, and considering the specific situation in the banking system in light of the external risks to the country's financial stability. Bank of Albania requirements were based on the standards issued by the Financial Stability Board (FSB) and EBA guidelines on RP indicators [Based on Directive 2014/59/EU establishing a framework for the recovery and resolution of credit institutions and investment firms sets out a Union-wide framework for crisis prevention, management, and resolution of these entities and specifying the minimum list of quantitative and qualitative indicators for the purposes of recovery planning]. During the RPpreparation process, the Bank of Albania started a continuous dialogue with banks, in order to recommend in due time the necessary improvements and steer the bank's work to achieve the desired results.

\section{Main Principles for a Sound Business Continuity Management of Banks}

The bank's activity relies on several critical resources (e.g. IT systems, communication systems, buildings). The purpose of preparing the RPis to reduce the operational, financial, legal, reputational and other material consequences arising from a disaster or extended interruption to these resources and consequent disruption to the institution's ordinary business procedures. Other risk management measures might be to reduce the probability of such incidents or to transfer their financial impact (e.g. through insurance) to third parties.RPs should be in place to ensure a bank reacts appropriately to emergencies and is able to maintain its most important business activities if there is disruption to its ordinary business procedures.
Banks should take into consideration the external data and performing scenario analysis of its exposure to severe business disruptions and assess (quantitatively and qualitatively) their impact. This analysis should cover all banking and financial activities and support units and management and take into account their interdependency. A specific independent function for following the RPor the operational risk management function [Directive 2006/48/EC Annex X, Part 3, Par. 4 which requires for AMA-institutions an Operational Risk Management function; the tasks of this function are described in the Guidelines on Validation par. 615-620 (published 2006) which is available at: http://www.cebs.org/documents/Publications/Standards---

Guidelines/2010/Stress-testing-guidelines/ ST_Guidelines. aspx. 41] should be actively involved. After all these analysis the results should enable a bank to define its recovery priorities and objectives.

A bank should have RPs for critical resources in place to enable it to return to ordinary business procedures in an appropriate timeframe. Any residual risk from potential business disruptions should be consistent with the institution's risk tolerance/appetite.

The RPs should be documented and carefully implemented. The documentation should be available within the business, support units and the upper management, and stored on systems that are physically separated and readily accessible in case of contingency. Appropriate training should be provided. Plans should be regularly tested and updated. Any challenges or failures occurring in the tests should be documented and analysed, with the plans reviewed accordingly.

\section{The Adoption of the Standards}

The IMF in its Country Report No. 14/79for the Albanian FSAP recommended [Albanian FSAP, IMF Country Report No. 14/79, 2014. Principle 16 "Conclude assessment of recovery and resolution plans of banks, especially of those banks indentified as systemically important. Provide written 


\section{International Journal of Science and Research (IJSR) \\ ISSN (Online): 2319-7064}

Index Copernicus Value (2013): 6.14 | Impact Factor (2014): 5.611

guidance to banks."] issuing a mandatory instruction for banks on RPs.

On February 26, 2014, The Supervisory Council of the Bank of Albania approved a mandatory Instruction on RPs to guide banks in the area of recovery planning. The Instruction determines the core principles, as well as supervisory requirements on the structure and contents of the RPs, and reporting requirements for banks. This guideline has tried to approach with what is prescribed by the EU Bank Recovery and Resolution Directive (BRRD) [The BRRD is the EU Directive that requires credit institutions and investment firms across the EU to develop recovery plans defining the measures they would adopt to restore their long-term financial viability in distressful situations. The Guidelines have been developed in accordance with Article 9(2) of Directive 2014/59/EU (BRRD) which mandates the EBA to specify a minimum list of quantitative and qualitative indicators for the purposes of recovery planning]. The recovery guideline provides the minimum list of qualitative and quantitative indicators that banks should include in their RPs and will function as triggers for the RPs.

The recovery guideline for Albanian banks sets the requirements that systemic important banks [On January 2015, Bank of Albania with decision no. 435of the Vice Governor categorized as systemic banks by Bank of Albania seven banks as per following: Raiffeisen Bank S.A.; Intesa Sanpaolo Bank Albania S.A.; National Commercial Bank S.A.; Tirana Bank S.A.; Credins Bank S.A.; AlphaBank Albania S.A; NBG Bank Albania S.A. The evaluation and categorization of banks as systemic important will be conducted on a yearly basis and by the end-March of every year, banks of systemic importance will submit te enhanced Recovery Plans to Bank of Albania, in line with the Guideline] in Albania should follow when drawing up their RPs which set out measures they would adopt to restore long-term financial viability in case of severe distress. Both qualitative and quantitative, indicators grouped into different categories such as capital, liquidity, profitability and asset quality are the minimum list that banks should include in their RPs. Macroeconomic and market-based indicators are also important to include in RPs of banks if relevant to their legal structure, risk profile, size and complexity of the characteristics of the bank and when the bank has the control of a banking group. All these indicators serve to identify the topics at which appropriate recovery measures should be considered. However, banks should not limit their set of RP indicators to the minimum list provided by the recovery guideline approved by BoA. They can add the list with other additional indicators provided by international financial authorities.

This guideline requires systemic important banksto adopt RPs and demonstrate their ability to operate during period of stress. It determines the core principles, as well as supervisory requirements on the structure and contents of the RPs, and reporting requirements for banks. Main requirements of this guideline:

1) Banks will draw up and update the RPs. Plans will be updated at least annually, with the purpose to reflect the possible changes compared to the previous option of the Plan, based on developments related to the bank's risk profile, marketconditions and other factors that may impact the recovery measures proposed in the Plan.

2) Banks will identify, in these plans, a sufficient number of possible recovery measures to be implemented, to deal with specific shocks on them, as well as systemic shocks. These measures should provide for the correction of critical situations of capitalisation and liquidity decrease, with the purpose to restore the stability of banks.

3) Banks, in case of failure to identify reliable recovery measures, shall develop, in their plans, other preliminary measures they would implement to improve their ability of recovery.

4) Banks will set forth in plans the respective management processes, terms in implementing them, and procedures to ensure timely implementation of recovery measures, whenever needed. Also, banks will appoint an administrator (Executive Director), who shall be at the same time a member of the Steering Council, and shall be responsible for the preparation process of the plan and its quality within the bank.

5) Banks shall include in the plans the needed information to assist the Bank of Albania to have effective relationships with the authorities that supervise the parent bank of subsidiaries or branches of foreign banks related to the recovery process. The Bank of Albania shall collaborate with these authorities at the process of banks recovery planning, with the purpose to obtain the commitment that parent banks will be able to handle effectively potential problematic situations, and will provide support with capital and liquidity for their subsidiaries and branches, according to their need.

6) Banks shall include:

a) Management. This shows the general framework of managing the processes for the possible development and implementation of the plan at the bank. Some key elements as per following:Policies and procedures for approval,confirmation that the plan has been reviewed by the internal audit, risk committee, or the external auditor, including a summary of their comments and recommendations; decision of the steering council of the bank approving the RP; the steering council shall approve the RP every time it changes in compliance with the recommendations of the Bank of Albania, or due to the regular updates; Relationships within the group/ crossborder banking activity, description of measures that are taken to provide the coordination and consistency amongst plans both at group and individual level; description how the bank shall assure that the necessary information for the possible implementation of the recovery measures will be made reliably and swiftly available to the decision-making during problematic situations. This information shall include, but is not limited to, the information that should be provided by the subsidiary/branch of foreign bank to the Bank of Albania, the information that will be shared between the subsidiary/branch of foreign bank and parent bank or the holding company, etc.

b) Strategic analysis. This shows a summarised analysis of the bank's structure and activity and the harmonisation of plan with its overall strategy. Some key elements as per following:Overall view of the bank, description of the overall structure of the bank or group, by clearly showing legal entities according to the assets' size; description of the

\section{Volume 4 Issue 12, December 2015}




\section{International Journal of Science and Research (IJSR) \\ ISSN (Online): 2319-7064}

Index Copernicus Value (2013): 6.14 | Impact Factor (2014): 5.611

general strategy of business and risk, and harmonization of plan with these strategies;description of the business model and main activities; description of main business lines and critical functions;information on the deposits covered by the Albanian Deposit Insurance Agency and the uncovered deposits;description of the relationships with banks and other entities, related to the important exposures or liabilities to the main counter parties; Relationships within the group/cross border banking activity, it provides the necessary within explanations on the position of the subsidiary/branch of foreign cross-border bank in Albania, as part of the group, by including: summary of business activity at group level, followed by supporting data, and the respective positioning and share of the bank within the group; description of bank's assets exposure within the group, funding relationships and any other agreement for financial support; description of capital inflows of the bank within the group and the guarantees within the group; description of operational dependence of the bank within the group, including an explanation on how the supporting functions within the group are organised and provided, for example related to information technology, risk management, auditing, etc.; description of how the RP of the group handles, if applicable, the activity in the territory of the Republic of Albania.

c) Possible recovery measures. This presents a consistent framework on the reporting of the recovery measures proposed by the bankrelated to implementation of any recovery measure, reliability, integration into existing processes, relationships within the group/ cross- border banking activity (when the bank is part of the cross-border group), indicators for the implementation of the RP. This last one, among others, should have in consideration the description of the management, control and decision making process to implement the RP, as well as the summary of the expected commitment with other parties outside the bank, including the Bank of Albania, the Albanian Insurance Deposit Agency and the Ministry of Finance; List of the key staff of the bank involved in the decision-making process.

d) Support by the Bank of Albania. This presents the bank analysis on the needs for liquidity support by the Bank of Albania and its ability to use this support. Some key elements as per following:banks will prepare an analysis on application modalities for using the support with liquidity by the Bank of Albania and/foreign liquidity by central banks, where they may have access, under problematic situations; banks will evaluate the circumstances under which banks may request support with liquidity by the Bank of Albania; an evaluation of factors that may impact the bank's ability to use the support with liquidity by the Bank of Albania, including the analysis of assets that may be used for this purpose and the liquidity amount that may be received based on these assets.

e) Possible measures of sale. This introduces in details the possible measures of sale available to the bank. These are recovery measures that forecast the sale of the bank's assets or its business lines. Some key elements as per following:banks will prepare the respective plans on the possible sale of assets/business' lines; possible purchasers; description of the management and control for the approval of the transaction; comments on possible issues related to the competitiveness; description of the possible legal restrictions; assessment of regulatory and tax implications; assessment of issues related to human resources and pensions;respective explanations related to diligence process and the confirmation that there will be no impediment in sharing the information, including the share of information with the Bank of Albania; potential purchasers of assets; explanation if the bank has considered previously the possibility of such sales and the description of the results of these efforts.

f) Communication Plan. This shows the internal and external communication plan, to accompany the recovery measures, summarising the issues that should be considered during the implementation of these measures to prevent the doubtless related to the continuation of the bank's activity and to maintain the confidence of markets and other parties of interest. Some key elements as per following: description of internal communication for the employees of the bank; description of external communication process for shareholders, supervisory authorities, counter parties, financial markets, investors, depositors and public at large; description of measures to be undertaken to manage the possible negative reaction of the markets.

In addition to FSAP recommendations [Albanian FSAP IMF Country Report No. 14/79, 2014. Principle 18 "Formulate requirements for problem loan management which would address the collection, restructuring, recovery and resolution of loans], on February 26, 2014, the Supervisory Council of the Bank of Albania approved the regulation [Approved by decision no. 10, dated 26.02.2014 of Supervisory Council of Bank of Albania]. "On the risk management from large exposures of banks" fully revised intending fair alignment with the rules and concepts of the new Bank of Albania regulation on capital adequacy and the new EU regime on large exposures (Regulation "On prudential requirements for credit institutions and investment firms" - Part III/Large exposures). This regulation provides for some more qualitative requirements for banks as well as related with the Steering Councilresponsibilities, in particular, for decision making process in cases of creation and restructuring of exposures to large borrowers as well as some requirements dealing with: development of large borrowers' recovery and resolution plans and their revision with a frequency not less than once a year; coordination and participation of banks in collective recovery and resolution plans with other banks, in case of exposures to the same large borrower (or group of connected borrowers), even when the exposure is not considered large, on an individual bank level. These recovery and resolution plans serve to the establishment of a NPL resolution, as well. In this background Bank of Albania did a project in cooperation with FinSAC (Financial Sector Advisory Center), a World Bank project, with the purpose to establish a NPL resolution framework. The project aims at bringing banks together in preparing a common Recovery and Resolution Plans (RRP) for large non-performing borrowers that were financed by more than a bank. Preparing of common RRPs by banks on common borrowers was determined as a regulatory requirement for large borrowers by Bank of Albania.

\section{Volume 4 Issue 12, December 2015}




\section{International Journal of Science and Research (IJSR) \\ ISSN (Online): 2319-7064}

Index Copernicus Value (2013): 6.14 | Impact Factor (2014): 5.611

\section{Conclusions}

- The RP is a bank's comprehensivelist of options addressing a range of severe financial stresses caused by idiosyncratic problems, market-wide stress or both.

- Banks (five systemic banks and two other banks due to their risk profile) submit to the Bank of Albania the RPs drafted in compliance with the provisions of the guideline no. 11, dated 26.2.2014, "On Recovery Plans", not later than the first quarter of each year.

- In general banks require assistance and guidance to confirm that they are heading in the right direction with the preparation of the RPs. Smaller banks seem to have the most difficulty in properly understanding the requirements.

- The Bank of Albania assesses the compatibility with the requirements of this guideline, the realisation and reliability of plans submitted by banks. Also, it communicates to banks the necessary recommendations to address the identified deficiencies and improvement the plans and monitor their implementation.

- The Bank of Albania has an on-going dialogue with banks, and carries out all the necessary assessments in the framework of on-site and off-site supervision, to be effectively sure on their ability to recover if needed, and the level of their operational willingness.

- The RP has a sufficiently clear description of the escalation and decision-making process. This ensures effective action to be taken in a timely manner and include procedures to be followed during recovery, including identification of the key people involved and their roles and responsibilities.

- The bank's Board of Directors gives the confirmation thatthe RPwas reviewed and approved.

\section{Recommendations}

- The RPs should be a living document, updated at least annually, and each time material changes to the bank's business/structure/risk profile take place;

- In addition to the more obvious and straightforward recovery options banks should consider radical options which could alter the bank's structure and business model. Banks should also identify any remedial actions that could be taken to improve the credibility and effectiveness of individual recovery options.

- The potential activation of recovery measures must be decided upon by the highest decision making authority of the bank, taking fully into account the specific circumstances at the moment. The plan should include warning limits, which require decision making on the part of the bank's management on the potential activation of the measures. The measures should be activated after close consultation with the Bank of Albania;

- It is useful to describe in the plan how the management is notified when warning indicators are reached, who is responsible for notifying management, what is the workflow from then on (meetings of committees, the board, etc.), then who is in charge for executing each segment of the measures to be undertaken according to business lines or (3LODM) three lines of defence model or another classification considered meaningful by the
bank;Also, the bank has to follow carefully the communication plan to ensure that stakeholders (internal and external) are given timely and appropriate information during the firm's recovery process.

- The bank must plan for the eventual materialization of a combination of risk scenarios rather than the occurrence of a single one at a time. Realistically, the occurrence of one risk scenario has natural implications on other aspects of the bank's risk profile (e.g. credit risk leads eventually not only to losses but also liquidity problems), etc.;

- The content of RPs should be proportionate to the nature, scale and complexity of the activities of the bank and its banking or financial group for consolidated supervision purposes. Also, the bank must describe in the plan the difficulties expected to accompany the implementation of recovery measures, and solutions proposed to mitigate them;

- In case of staff and business line restructuring, the bank must take into account the systemic importance of business lines before shutting them down. Recovery measures should not defeat the ultimate purpose of RPs that is maintaining the core services, the disruption of which is harmful to financial stability.

- The range of indicators identified to activate the implementation of the RPshould go beyond regulatory capital and liquidity ratios and include internal quantitative and qualitative metrics from the bank's overall risk management framework. Banks should also consider early warning indicators to identify emerging signs of stress. The calibration of indicators should be forward looking to allow sufficient time for corrective actions to be taken.

- For the option of reducing lending, it is important to specify the criteria for identifying key customers, and customers who are going to be served regardless of reductions (exp. systemically important customers, financial institutions served by the bank or large corporations, etc.)

- Banks should insert the RP into the bank's existing risk management framework. This will allow the plan to be implemented efficiently and effectively when banks encounter severe stress conditions.

- Banks should have an operational plan for accessing central bank liquidity facilities.

\section{References}

[1] CEBS, Consultation paper on the Guidebook on Internal Governance (CP 44), 2010

[2] Financial Stability Board - Key Attributes of Effective Resolution Regimes for Financial Institutions, October 2011

[3] Albania FSAP, IMF Country Report No. 14/79

[4] Directive 2014/59/EU

[5] EU Bank Recovery and Resolution Directive

[6] Presentations on RRP, Ernest \& Young, 2013

[7] Publications of internal or international financial institutions on RRPs

\section{Volume 4 Issue 12, December 2015}

